\title{
Enhancing Learners' Vocabulary Acquisition by Crossword Puzzle Game
}

\author{
Juwita Nurul Alda ${ }^{1}$, Shafrida Wati ${ }^{2 凶}$ \\ ${ }^{1}$ English Education Department, Institut Agama Islam Negeri Langsa, Aceh, Indonesia, \\ ${ }^{2}$ English Education Department, Institut Agama Islam Negeri Langsa, Aceh, Indonesia \\ email: shafridawaty@iainlangsa.ac.id
}

Received:

May 07, 2021

Revised:

May 27, 2021

Accepted:

June 23, 2021

\section{ABSTRACT}

This study aimed at developing learners' vocabulary acquisition by using a crossword puzzle game at an English course in Langsa, Aceh Province. It further explored how the technique helped the learners learned and acquired English vocabulary. This study was a Classroom Action Research (CAR) and it applied steps of action research set out by Kemmis and McTaggart, which encompasses planning, implementation, observation, and reflection. 17 learners were selected as the subject of this research purposively. Observation, interviews, and vocabulary tests were conducted to collect the data. The findings revealed that the use of crossword puzzle game developed the learners' vocabulary acquisition effectively, as whole participants achieved the Minimum Mastery Criterion score (KKM), which was 75 , successfully. The proportion of those who reach the score was $35,29 \%$ at the first cycle and the number was rose gradually to $100 \%$ at the third cycle. The study also found that the implementation of the crossword puzzle promoted an effective languagelearning atmosphere. The learners engaged in the learning process and got involved in the activities enthusiastically. It developed the learners' curiosity to complete the task and enhanced their self-confidence in learning English as they worked in groups. It also provided opportunities for the students to practice the vocabulary and to develop pronunciation.

Keywords: Crossword Puzzle; Game; Vocabulary

\section{INTRODUCTION}

Vocabulary is one of the crucial language components besides grammar and pronunciation. Acquiring adequate vocabulary allows people to use the language both in written and spoken activities (Hatch \& Brown, 1995). Not only to communicate but acquiring adequate vocabulary also helped people to comprehend information written in the foreign language (Jackson, 2002). Harmer (2002) further classifies two categories of vocabulary, which are active and passive vocabulary. Active vocabulary or productive vocabulary is words that someone learned and used in daily life. In a language-learning context, learners mostly use the vocabulary in speaking and writing activities. Passive vocabulary or receptive vocabulary refers to words that students recognized and understood when they interact with others. The learners mostly use them both in listening and reading activities. In other words, passive vocabulary is all words that students heard and read. 
Nevertheless, having a lack of lexical knowledge avoids an individual to express his thoughts clearly and fails to acquire the language skills successfully. The majority of learners, especially those who learn English as a foreign language, faced problems in acquiring the target language due to inadequate vocabulary they had. Therefore, to facilitate an engaging activity at the foreign language learning is considerably beneficial to attract learners' enthusiasm in learning, to enable them to recall the vocabulary, and to use them. One of the engaging activities to teach vocabulary is the crossword puzzle game. It is considered an interesting and enjoyable activity, which consists set of rules, played individually or collaboratively. It promotes an engaging learning atmosphere that allows learners to grasp the information easily. It provides an effective impact on learners' vocabulary development (Melasari, et al, 2019, \& Wardana, 2016). The technique provides the students with the opportunities to memorize massive vocabulary (Njoroge, Ndung'u, \& Ghatigia, (2013). Crossword puzzle also grows learners' curiosity and motivation in learning activities. Sallis (2006) adds that a crossword puzzle provides a new technique for students to learn vocabulary, which helps to develop learners' vocabularies, enhances their lexical knowledge, and builds teamwork, as they work cooperatively with friends to complete the puzzle.

Game is a technique that encourages many learners to sustain their interests and works in learning (Sahrin \& Hasan, 2019. The activity also helps teachers to know which language is useful and meaningful (Wright, 1993). Harmer (1999) explains that games give learners a feeling of competition to participate in the process of learning vocabulary and motivates them to repeat the vocabulary enthusiastically. $\mathrm{He}$ also maintains that games that depend on an information gap encourage learners to negotiate with a partner to solve a puzzle, draw a picture, and find similarities and differences between the pictures. Games are associated with a feeling of joy and happiness. For this reason, most learners will appreciate games and enjoy participating in them even if they are not familiar with the rules. Therefore, it is obvious that game has a role as an interesting strategy to help teachers in managing classroom to be more effective, pleasant, attractive, enjoyable, interesting, and not boring for students. In other words, the game provides many advantages in teaching and learning especially the vocabulary.

Dealing with the crossword puzzle game, there are some types of puzzles include oral and picture crosswords. The instruction for the first kind of puzzle is given orally, which may initiate listening activity, while the latter is stated in pictures. Pictures do not only bring images of reality, but they can also function as a fun element in the class as they may create an engaging learning atmosphere (Joklova, 2009). Pictures can also help learners to imagine the object of a word. Besides, the students tend to remember what they see. It may ease them to recognize and memorize the English vocabulary given to them. The third is the object crossword is the crossword in which the clue is written on the object. Instructors only provide the blank puzzle without clues. Placing the items around the room, each of which is labeled with its clues number. Having the students move around the room to different stations and allow them to pick up the objects as they complete the puzzle. This tactile version of the puzzle is effective for 
those who are hands-on learners. This type of puzzle is appropriate to teach massive vocabulary.

\section{METHOD}

This research was classroom action research (CAR). Action research is a systematic inquiry conducted by teacher researchers, principals, school counselors, or other stakeholders in the teaching and learning environment to improve educational practices (Mills, 2000). This study used steps of action research set out by Kemmis and McTaggart as shown in the following figure:

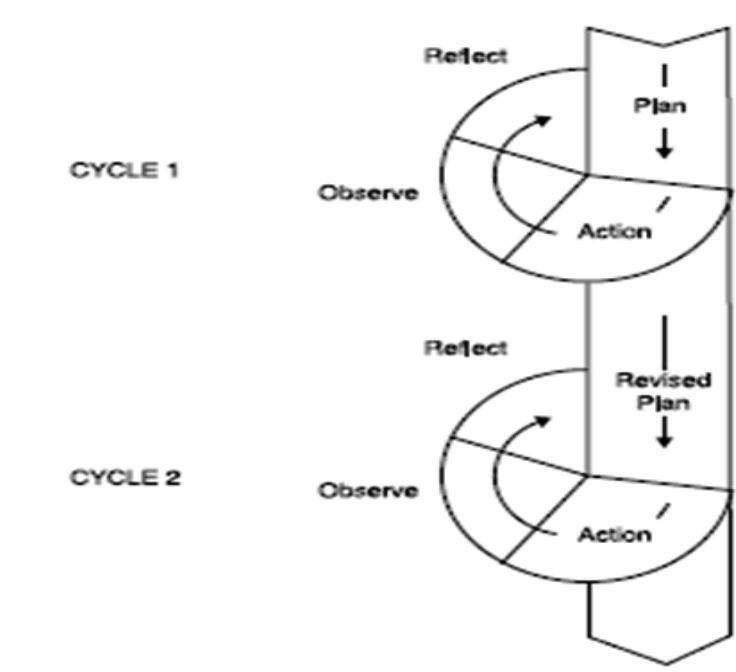

Figure 1.1: Kemmis and Mc Taggart CAR Cycles

At the first step, the action researcher designed general plans for action. At the action phase, the researcher implemented the teaching based on the planned scenario. The observation stage was conducted once with the action. Kemmis \& Taggart (1988) explained observation functions to document the effects of informed action. Reflection means to reflect on these effects as the basis for further planning, subsequent, and critically informed action. At this phase, the results of the action were described and evaluated. The general plan was then revised and the second action was planned, implemented, monitored, and evaluated.

The research was conducted on July 2020. The learning center has 160 students, consisting of 90 male and 70 female students, and 15 teachers. The subject of this research was 17 learners of an English class. Sugiyono (2016) describes determining samples for the naturalistic study is different from conventional studies, which is not based on statistical calculations. The sample chosen serves to get more information and not to generalize. Therefore, the subject was selected purposively to obtain clear and in-depth information. Satori (2007) defines purposive sampling as a sampling technique that is determined by adjusting to specific research aims or considerations. Purposive Sampling is often called judgment sampling, simply interpreted as selecting 
a sample that is adjusted to a specific purpose. The techniques used for collecting the data were interview, observation, and test.

An interview is an approach to get information or data by using verbal interaction (Suwartono, 2007). The interview was conducted after the action stages at each cycle. The researchers interviewed the English teachers and the students. It aimed to find out the students' experience in learning vocabulary by using the crossword puzzle game, their perception about learning by using the technique, and changes they may perceive, especially their vocabulary acquisition as a result of their involvement in the research. The researcher applied an in-depth interview, which provides detailed information. Moreover, the researchers also observed the teaching and learning activities.

Observation is the process of gathering open-ended, firsthand information by observing people and places at a research site (Creswell, 2005). The researcher was involved directly in the classroom activity. In this research, observation aimed at getting the data about the process of teaching, learning vocabulary by using crossword puzzle, the teachers' obstacles in teaching vocabulary, and the students' problems in learning vocabulary by using crossword puzzle. The observation was carried out at the same time as the action. Observation has the function of documenting the effects of critical informed action. Furthermore, the researchers also provided tests. The tests were given after implementing the action. Based on its definition, a test is a set of questions or other practices or devices used to measure the kills, intelligence, and ability of an individual or a group (Arikunto, 2010). The types of tests given were memorizing and matching words tests.

Furthermore, to analyze the data, the researcher applied procedures of analyzing data constructed by Miles and Huberman. It is a process to systematically search and compile data obtained from interviews, field notes, documentation, by organizing them into categories, describing them into units, synthesizing, arranging into patterns, choosing what is important and what will be learned, and making conclusions so that they were easy to be understood. In this study, the researcher used the procedure of data analysis based on Miles and Huberman which is involving three steps; data reduction, data display, and conclusion drawing.

Data reduction refers to the process of selecting, focusing, simplifying, abstracting, and transforming the 'raw' data that appear in written-up field notes. As data collection proceeds, the further episode is data reducing through conducting summaries, coding, teasing out themes, making clusters, making partitions, writing memos and the data reduction/transforming process continues after fieldwork until final reports complete. Data display defines as an organized assembly of information that permits conclusion drawing and action taking. Looking at displays helps us to understand what is happening and decide further analysis or action to do base on that understanding. The next steam of analytic activity is conclusion drawing and verification. From the beginning of data collection, classroom research has started to decide what things mean, noting regularities, patterns, explanations, possible configurations, causal flows, and propositions. Competent researchers hold these 
conclusions lightly, maintaining openness and skepticism. It may vague at first but then it increases explicitly and grounded.

\section{FINDINGS AND DISCUSSION}

The researchers conducted the action research for three cycles. Each cycle covers planning, action, observation, and reflection stages. The research was conducted in three cycles, which consisted of three meetings each.

\section{a. Cycle I}

(1) Meeting 1

a) Planning

At the planning stage, the researcher developed some activities such as designing materials to teach, collecting references, designing lesson plans, preparing the media, constructing the observation sheets for teachers and learners, and constructing tests to evaluate the learning.

b. acting

The researcher started to implement the teaching on Friday, July $3,{ }^{\text {rd }} 2020$. The researcher started the class by introducing the topic, which was about school supplies. The researcher initiated some questions about the topic-specific vocabulary. She introduced the crossword puzzle and explained its procedures. She asked the students to sit in groups, gave instruction, and distributed a clue picture of crossword puzzles to each group. She asked the students to accomplish the crossword based on the researcher's guidance.

c. Observing

During the teaching and learning activities, the researcher monitored the students' involvement in every activity provided in the classroom. She found out that they were difficult to identify objects in English and acted passively at the beginning of the lesson. The researcher evaluated the students learning by asking them to recall the vocabulary they have learned.

\section{d. Reflecting}

After analyzing the result of the action, the researcher concluded that the students faced challenges to identify objects in English. They could not spell words and produce words with proper pronunciation. Results of the test also showed that the students failed to achieve the minimum mastery criterion score (KKM), which was 75. Therefore, the researcher planned to add some approaches to teach the students. She will motivate them to learn, provide short and clear instruction, and insist more on repetition, and provide extra time to complete the puzzle.

(2) Meeting 2

a. Planning

The researcher developed a lesson plan, designed materials for hospital topics, preparing the crossword puzzle to include the clues and grid squares, designing a classroom observation sheet, and constructing a test.

b. Acting 
The second meeting was conducted on Saturday, July $4^{\text {th }}, 2020$ the researcher started the lesson by greeting the students and reviewing the previous vocabulary. Then, she introduced the topic to the students and asked about their background knowledge about the topic. The researcher asked them about the topic of a hospital. She initiated some short questions dealt with a hospital, such as have they ever been to the hospital, have they seen a doctor, and what did they see in the hospital. She engaged the students in the discussion and motivated them to respond by using English and the Indonesian language. Then, the researcher wrote some vocabulary about the hospital and the learners noted them down. She invites them to say the words aloud to practice the pronunciation. She repeated saying the words several times. She elaborated the vocabulary by using the pictures to insist on the meaning. Then, she asked them to recall the vocabulary. Following that, she divided them into groups and continued studying the vocabulary.

c. observing

The researcher observed that the students tend to keep silent at the beginning of the class. They found difficulties to recall the vocabulary they have learned earlier. When the researcher, repeated the vocabulary by uttering aloud they practiced them in choral. As the result, the students acquired few vocabularies. The students were enthusiastically participating in the group work, especially when they will accomplish the puzzle. They worked together to fulfill the clues. They showed that they were not afraid of making mistake. They expressed them self happily when they successfully complete the puzzle. They memorized the vocabulary together by reading them aloud and helped one another when one of them forgets the words. Nevertheless, the result of their vocabulary test was still unsatisfied.

d. Reflecting

Based on the observation and test results in cycle I meeting 2, the researcher concluded that the students' vocabulary was still poor. It showed from them the number of the students who obtained a lower score than the minimum mastery criterion score (KKM). The researcher considered developing more vocabulary practice as well as pronunciation. The researcher planned to continue using the puzzle, as she analyzed that the learners started to speak up when they sit in groups. They seemed enthusiastically discussing with friends to accomplish the task. The researcher considered that the learners felt secure when they worked in a team. Working in groups tends to release their anxieties as they worked together to complete the task.

(3) Meeting 3

a. Planning

The researcher continued to design the lesson plan. She prepared the puzzle and the clues, made an observation sheet, and constructing a test, which matching words with the alphabet cards.

b. Acting

The researcher conducted the teaching on Sunday, July $5^{\text {th }}, 2020$. She started the class by reviewing the previous vocabulary they have learned. She then introduced the 
learning topic. She wrote some clues of letters on the whiteboard and asked students to guess. The words were related to the topic-specific vocabulary. Then, she invited students to find out more vocabulary through the crossword puzzle.

c. Observing

The learning process started interactively. Few students seemed still reluctant to participate before the group activity started. Most of the students, however, show their willingness to participate cooperatively in collaborative work.

d. Reflecting

After analyzing the result of action in cycle 3 meeting 1, the researcher concluded that there was a slight increase in the students' vocabulary. It showed from the number of students who obtain scores higher than the KKM. The researcher also found that, their pronunciation was better than earlier. The researcher decided to continue the treatment as well to insist more on practice.

The researcher summarized the results of students' vocabulary test from the first, the second, and the third meeting as described in the following table:

Table 1.1 Scores of Tests in Cycle I

\begin{tabular}{|c|c|c|c|c|}
\hline \multirow{2}{*}{ No } & \multirow{2}{*}{$\begin{array}{c}\text { Students' } \\
\text { Initials }\end{array}$} & \multicolumn{3}{|c|}{ Meetings in Cycle I } \\
\cline { 3 - 5 } & Meeting $\mathbf{1}$ & Meeting 2 & Meeting 3 \\
\hline 1. & AIF & 60 (Good) & 65 (Good) & 85 (Excellent) \\
\hline 2. & AA & 15 (Inacceptble) & 50 (Fair) & 70 (Good) \\
\hline 3. & AL & $\begin{array}{c}25 \\
\text { (Inacceptable) }\end{array}$ & 50 (Fair) & 60 (Good) \\
\hline 4. & AKP & 50 (Fair) & 50 (Fair) & 75 (Good) \\
\hline 5. & CDL & 55 (Good) & 70 (Excellent) & 80 (Excellent) \\
\hline 6. & CMA & 35 (Fair) & 35 (Fair) & 55 (Good) \\
\hline 7. & DF & $\begin{array}{c}25 \\
\text { (Inacceptable) }\end{array}$ & 30 (Fair) & 45 (Fair) \\
\hline 8. & HD & 45 (Fair) & 50 (Fair) & 75 (Good) \\
\hline 9. & KR & $\begin{array}{c}25 \\
\text { (Inacceptable) }\end{array}$ & 50 (Fair) & 50 (Fair) \\
\hline 10. & KK & 30 (Fair) & 30 (Fair) & 75 (Good) \\
\hline 11. & M & $\begin{array}{c}25 \\
\text { (Inacceptable) }\end{array}$ & 45 (Fair) & 45 (Fair) \\
\hline 12. & MJ & $\begin{array}{c}25 \\
\text { (Inacceptable) }\end{array}$ & 30 (Fair) & 50 (Fair) \\
\hline 13. & MY & 50 (Fair) & 30 (Fair) & 55 (Good) \\
\hline 14. & MH & 35 (Fair) & 45 (Fair) & 45 (Fair) \\
\hline 15. & PA & $\begin{array}{c}25 \\
\text { (Inacceptable) }\end{array}$ & 40 (Fair) & 65 (Good) \\
\hline 16. & SSR & 65 (Good) & 65 (Good) & 75 ( Good) \\
\hline 17. & SAA & $\begin{array}{c}20 \\
\text { (Inacceptable) }\end{array}$ & 30 (Fair) & 60 (Good) \\
\hline
\end{tabular}




\section{\begin{tabular}{l|l|l|l|} 
Total Score & $\sum x=610$ & $\sum x=765$ & $\sum x=1.065$
\end{tabular}}

\section{b. Cycle II}

(1) Meeting 1

a. Planning

The researcher continued the teaching. She began the activity by designing lesson plan, designing some activities implemented in the classroom, preparing the teaching materials include the sources and the teaching media, preparing the puzzle with the clues and the grid square, developing the observation sheet, and constructing a test.

b. Acting

The first meeting on cycle 2 was conducted on Monday, July $6^{\text {th }}, 2020$.The researcher introduced the topic, which was about parts of the body. She developed the learners' background knowledge by asking them to mention parts of body in English. The students recorded difficult vocabulary on their book. She asked them to repeat uttering the vocabulary and checked whether they can recall them or not. At the next stage, she asked the students to work in groups. She organized the groups and the students had new groups members to work with. They accomplished the puzzle and practice recalling the vocabulary collaboratively.

c. Observing

Based on the researcher observation, most of the students participated in the teaching and learning process enthusiastically. The students were eagerly learning with new team members. That was effective to motivate students learning and sharing with new friends and the classroom was also not monotonous. The researcher also distributed test to find out their vocabulary development.

d. Reflecting

After analyzing the result of action in cycle II meeting 1, the researcher found that the students' vocabulary was improved. Several students achieved higher score than the KKM. which is 75 . It meant that the number of vocabulary they acquired were improving. The researcher noticed than providing engaging and challenging activity such as completing puzzle to figure out vocabulary attract students to learn enthusiastically. The result of their learning was also improved. Therefore, the researcher continued the teaching activity to ensure all students experience the progress.

(2) Meeting 2

a. Planning

The researcher designed a lesson plan for the next teaching, developed materials, collected sources. She also prepared the research instrument and the puzzle puzzle including the grid and the clues, designed the observation sheet, and constructed the test.

b. Acting

The second meeting for the teaching was conducted on Tuesday, July $7^{\text {th }}, 2020$. The researcher started the class by greeting the students and asked simple short 
questions in English to initiate students to practice using the target language. Then, she introduced the topic and introduced the topic-specific vocabulary, which is about transportation. The students started to copy some vocabulary on the whiteboard on their notes. She invited them to practice the vocabulary in choral. She showed how to pronounce the vocabulary correctly and asked the students to repeat it. Following that, she asked them to close their notes and checked whether they can recall the vocabulary. The students recalled some vocabulary about the topic fluently. At the next stage, she formed groups and directed the students to complete words in the puzzle.

c. Observing

The teaching and learning process runs effectively. Most of the students participated in the classroom activity eagerly. They practiced the word aloud. They competed to be the first to answer the question from the researcher. To check their vocabulary development, the researcher then distributed the test.

d. Reflecting

The teaching and learning activity progress based on the plan. The classroom activities were implemented systematically. The majority of the students participated in the learning activities. They showed enthusiasm when the teacher started to divide groups. The number of students who achieve the KKM score was also increasing. The researcher decided to continue the meeting to ensure that all students experience the progress.

(3) Meeting 3

a. Planning

The researcher started to plan a meeting by designing a lesson plan, developing material, collecting references and sources for teaching, preparing the media, constructing the observation sheet and test.

b. Acting

The third meeting was conducted on Wednesday, July $8^{\text {th }}, 2020$. The researcher asked the students to recall the vocabulary they have learned at the previous meeting. She then showed some pictures related to the topic they would learn to initiate the learning. She then asked the students to mention the vocabulary in the pictures, which was about the animal. She provided the clues, gave some letters, and asked the students to complete the words. Following that, they conducted a puzzle activity to figure out more vocabulary about the topic.

c. Observing

The result of observation showed that the students were able to mention most of the vocabulary they learned earlier. Some of them were also able to produce the words with proper pronunciation. They get involved in the learning activities, especially at puzzle game activity. To identify reliable improvement, the researcher distributed a test. 


\section{d. Reflecting}

Based on the analysis of the action at meeting 3 cycles 2, the researcher concluded that there was a significant increase in the students' vocabulary. The result of the test also indicated that the majority of the students achieved a satisfying score, which was higher than the KKM. They were also able to produce the vocabulary with proper pronunciation. Therefore, the researcher decided not to continue further action. The results of the learners' test score of the second cycles are described in the following table.

Table 1.2 Scores of Tests in Cycle II

\begin{tabular}{|c|c|c|c|c|}
\hline \multirow{2}{*}{ No } & \multirow{2}{*}{$\begin{array}{c}\text { Students' } \\
\text { initials }\end{array}$} & \multicolumn{3}{|c|}{ Meeting Cycle II } \\
\cline { 3 - 5 } & Meeting $\mathbf{1}$ & Meeting 2 & Meeting 3 \\
\hline 1. & AIF & 85 (Excellent) & 95 (Good) & $\begin{array}{c}100 \\
\text { (Excellent) }\end{array}$ \\
\hline 2. & AA & 75 (Good) & 85 (Fair) & 80 (Excellent) \\
\hline 3. & AL & 60 (Good) & 80 (Fair) & 85 (Excellent) \\
\hline 4. & AKP & 60 (Good) & 85 (Fair) & 90 (Excellent) \\
\hline 5. & CDL & 80 (Excellent) & 90 (Excellent) & $\begin{array}{c}100 \\
\text { (Excellent) }\end{array}$ \\
\hline 6. & CMA & 65 (Good) & 80 (Excellent) & 80 (Excellent) \\
\hline 7. & DF & 30 (Fair) & 75 (Good) & 80 (Excellent) \\
\hline 8. & HD & 70 (Good) & 80 (Excellent) & 80 (Excellent) \\
\hline 9. & KR & 45 (Fair) & 70 (Good) & 80 (Excellent) \\
\hline 10. & KK & 60 (Good) & 85 (Excellent) & 85 (Excellent) \\
\hline 11. & M & 50 (Fair) & 80 (Excellent) & 80 (Excellent) \\
\hline 12. & MJ & 55 (Good) & 80 (Excellent) & 80 (Excellent) \\
\hline 13. & MY & 75 (Good) & 85 (Excellent) & 85 (Excellent) \\
\hline 14. & MH & 70 (Good) & 80 (Excellent) & 80 (Excellent) \\
\hline 15 & PA & 65 (Good) & 80 (Excellent) & 80 (Excellent) \\
\hline 16 & SSR & 75 (Good) & 85 (Excellent) & $\begin{array}{c}100 \\
\text { (Excellent) }\end{array}$ \\
\hline 17 & SAA & 75 (Good) & 85 (Excellent) & $\begin{array}{c}100 \\
\text { (Excellent) }\end{array}$ \\
\hline & Total Score & $\sum \mathbf{x}=1.095$ & $\sum \mathbf{x}=1.400$ & $\sum \mathbf{x}=1.465$ \\
\hline
\end{tabular}

c. Analysis of the Whole Cycles

The researcher-analyzed results of students' performance at the whole meeting, as following: Cycle I

a) Meeting 1

$$
\bar{X}=\frac{\sum X}{\sum n}
$$




$$
\begin{aligned}
& \bar{X}=\frac{610}{17} \\
& \bar{X}=35,8
\end{aligned}
$$

Thus, the mean of meeting 1 in cycle I was 35,8 .

$f$

$\mathrm{P}=-\mathrm{x} 100 \%$

$n$

$$
\begin{aligned}
P & =\frac{0}{17} \times 100 \% \\
& =0 \%
\end{aligned}
$$

The percentage in cycle I meeting 1 was $0 \%$.

b) Meeting 2

$$
\begin{aligned}
& \bar{X}=\frac{\sum X}{\sum n} \\
& \bar{X}=\frac{765}{17} \\
& \bar{X}=45
\end{aligned}
$$

The mean of meeting 2 in cycle I was 45 .

$$
\begin{aligned}
& \mathrm{P}=\frac{f}{n} \times 100 \% \\
& \mathrm{P}=\frac{0}{17} \times 100 \% \\
& =0 \%
\end{aligned}
$$

The percentage in cycle I meeting 2 was $0 \%$.

c) Meeting 3

$$
\begin{gathered}
\bar{X}=\frac{\sum X}{\sum n} \\
\bar{X}=
\end{gathered}
$$




$$
\bar{X}=62,64
$$

The mean of meeting 3 in cycle I was 62,64 .

$$
\begin{aligned}
\mathrm{P}= & -\frac{f}{n} \times 100 \% \\
\mathrm{P} & =\frac{6}{17} \times 100 \% \\
& =35,29 \%
\end{aligned}
$$

Thus, the percentage in cycle I meeting 3 was $35,29 \%$.

From the above results, it can be seen that the students' average score at cycle I, meeting 1 was unsatisfactory. The researcher noted that the students faced difficulties to recalling vocabulary they have learned. Based on the test result, the average of the students' score at the second action, in cycle I was 45 and the proportion was $0 \%$. The score then improved slightly to 62,64 , or about $35,29 \%$ at the third meeting. It can be concluded that the actions at the first cycle were unsuccessful. Thus, the researcher developed the second cycle and improved the action. The researcher then continued cycle II to reach the target.

Cycle II

a) Meeting 1

$$
\begin{aligned}
& \bar{X}=\frac{\sum X}{\sum n} \\
& \bar{X}=\frac{1.095}{17} \\
& \bar{X}=64,41 \\
& \text { Thus, the mean score of meeting } 1 \text { in cycle II was } 64,41 . \\
& \mathrm{P}=\frac{-\mathrm{f}}{n} \times 100 \% \\
& \mathrm{P}=\frac{6}{17} \times 100 \%
\end{aligned}
$$




$$
=35,29 \%
$$

The percentage of meeting 1 , cycle II meeting was 35,29\%.

b) Meeting 2

$$
\begin{aligned}
& \bar{X}=\frac{\sum X}{\sum n} \\
& \bar{X}=\frac{1.400}{17} \\
& \bar{X}=82,35
\end{aligned}
$$

The mean score of meeting 2 in cycle II was 82,35.

$$
\begin{aligned}
\mathrm{P} & =\frac{f}{n} \times 100 \% \\
\mathrm{P} & =\frac{16}{17} \times 100 \% \\
& =94,11 \%
\end{aligned}
$$

The percentage of cycle I meeting 2 was 94,11\%.

c) Meeting 3

$$
\bar{X}=\frac{\sum X}{\sum n}
$$$$
\bar{X}=
$$

$$
\bar{X}=86,11
$$

The means score of meeting 3 in cycle II was 86,11.

$$
\begin{aligned}
\mathrm{P} & =\frac{f}{n} \times 100 \% \\
\mathrm{P} & =\frac{1}{17} \times 100 \% \\
& =100 \%
\end{aligned}
$$


Thus, the percentage of meeting 3 cycles II was $100 \%$.

There was a significant improvement in students' vocabulary mastery at the second cycle. It can be identified through students' average score that the students obtained in the last meeting of cycle II, which was 86,11 , or about $100 \%$. It can be said that the students' vocabulary achievement was satisfactory due to the use of crossword puzzles in the process of vocabulary learning. The researcher decided to end the action due to the students have reached the KKM score successfully.

Table 4.3 Thestudents' score of Cycle I and Cycle II

\begin{tabular}{|c|c|c|c|c|c|c|}
\hline \multirow{2}{*}{ Meeting } & \multicolumn{2}{|c|}{ Mean } & \multicolumn{2}{c|}{ Persentage } & \multicolumn{2}{c|}{ Total Student } \\
\cline { 2 - 7 } & Cycle I & Cycle II & Cycle I & Cycle II & Cycle I & Cycle II \\
\hline 1 & 35,8 & 64,41 & $0 \%$ & $35,29 \%$ & 0 & 6 \\
\hline 2 & 45 & 82,35 & $0 \%$ & $94,11 \%$ & 0 & 16 \\
\hline 3 & 62,64 & 86,11 & $35,29 \%$ & $100 \%$ & 6 & 17 \\
\hline
\end{tabular}

All students failed to reach the standard score at the first and the second meeting of cycle 1 . Then, it showed slight progress, which the number of students who reached score 75 above was 6 students in the third meeting of cycle 1 . The number then increased dramatically up to 75 above, or for about 17 students at the third meeting of cycle II. The proportions of the cycle I was $35,29 \%$ and it increased significantly to $100 \%$ at the last meeting of Cycle II.

The findings above indicated that the use of crossword puzzles improved students' vocabulary mastery. It was because the technique contributed to an engaging learning atmosphere. The learners admitted that they were interested in learning the vocabulary by using the media and it helped them to learn English vocabulary easily. The use of the media promoted teamwork and developed students' motivation to learn.

\section{CONCLUSION}

Crossword puzzle game is considered an effective technique to improve students' vocabulary acquisition. Results of observation and test showed that the students experienced gradual progress in their vocabulary. It assisted the students to memorize new vocabulary and grasp the meaning of words effectively as they use the media in learning. It involved physical activity in learning the vocabulary, which attracts students to learn enthusiastically. It promoted the students to work collaboratively as they helped another to memorize and recall the vocabulary. It also provided a chance for the students to spell and pronounce words successfully. Some advantages of the techniques were it promoted an engaging learning atmosphere, it developed learners' self-confidence in learning English, it developed teamwork which enhanced cooperation among peers and not competition. Therefore, it is suggested that the 
English teachers at the learning center may continue to use the technique to support the teaching and learning, especially the vocabulary as it promoted active learning.

\section{ACKNOWLEDGMENTS}

The researchers expressed their gratitude to the principals, teachers, and students of the learning center for the collaboration to conduct this research to solve one of the students' problems in learning vocabulary.

\section{REFERENCES}

Andrew W. (1993). Games for Language Learning, New Edition: Cambridge: Cambridge University Press.

Arikunto, A. (2006). Prosedur Penelitian: Suatu Pendekatan Praktek: Jakarta. PT.Rineka Cipta.

Creswell J.W. (2005). Educational Research: New Jersey. Prentice Hall.

Dhand H. (2008). Techniques of Teaching: New Delhi. APH Publishing.

Edward S. (2006). Total Quality Management in Educatio: Jogjakarta. IRCiSoD.

Evelyn H. \& Cheryl Brown. (1995). Vocabulary, Semantic, and Language Education: Cambridge. Cambridge University Press.

Harmer, J. (2002). The Practice of English Language Teaching:New York. Longman.

Hatch, B. E., \& Cheryl. (1995). Vocabulary, Semantic, and Language Education: Cambridge. Cambridge University Press.

Hornsby, A.S. (2006). Oxford Advanced Learner's Dictionary: Oxford. Oxford University Press.

Howard J. (2002). Grammar and Vocabulary: London. Rutledge.

Hopkins D. (1998). A Teacher's Guide to Classroom Research: New York. McGraw-Hill.

Jackson, H. (2002). Grammar and Vocabulary: London. Rouletdge.

Jim S. (1994). Learning Teaching English. Heinemann Publishers Oxford.

John E. (1991). Action Research for Educational Change: Philadelphia. Open University Press.

Joklová K. (2009). Using Pictures in Teaching Vocabulary: Czechia. Masaryk University.

Katrina E.H. (2015). Phenomenology and Educational Research. International Journal of Advanced Research. (3)8. 251. 
Kemmis., \& McTaggart. (1988). The Action Research Planner: Geelong: Deakin University.

Kunandar. (2008). Langkah Mudah Penelitian Tindakan Kelas Sebagai Pengembangan Profesi Guru: Jakarta. Rajawali Pers.

Lee, W.R. (1980). Language Teaching Games and Context: 2nd Edition: Oxford. Oxford University Press.

Longman. (2000). Learners' Dictionary of American English: New York. Pearson Education.

Melasari., Krisna, I., \& Deri., S. N. (2019). The Effect of Using Crossword Puzzle towards Students' Vocabulary Mastery in the Eleventh Grade Students of SMA Muhammadiyah 2 Bandar Lampung in Academic Year 2017-2018. JEES: Journal of English Education Studies. (2).1. 67-73.

Mills G.E. (2000). Action research: A Guide for the Teacher Researcher: New York. Prentice-Hall.

Napa. (1991). Vocabulary development skills: Yogyakarta. Kanisius.

Njoroge M.C., R.W Ndung'u., \& Gathigia. (2013). ”The Use of Crossword Puzzles as a Vocabulary Learning Strategy: A Case of English as a Second Language in Kenyan Secondary Schools". International Journal of Current Research. (5) 2. 313-321.

Nobert S., \& McCharty M. (1997). Vocabulary Description Acquisition and Pedagogy: UK. Cambridge University Press.

Sallis, E. (2006). Total Quality Management in Education: Jogjakarta. IRCiSoD

Satori D. (2007). Metodologi Penelitian Kualitatif: Bandung. Alfabeta.

Sahrin. V., \& Hasan, M. (2019). Increasing Students' Vocabulary Acquisition by Master and Mastery Cards Game. JOALL: Journal of Applied Linguistics and Literature. (4)1. 69-76. Doi.10.33369/joall.v4i1.6342.

Sugiyono. (2016). Metode Penelitian Kuantitatif, Kualitatif, dan R\&D: Bandung: Alfabeta,

Syaeful R.M (2013). English Education Journal (http://journal.unnes.ac.id/sju/index.php/eej/article/download/2716/2504/

Wardana. S. H. (2016). The Analysis of Implementing Crossword Puzzle at Seventh Grades on Mts Sutrya Buana Malang. Unpublished Thesis. http://eprints.umm.ac.id > jiptummpp- gdl-radenso.

Wright, A. (1993). Games for Language Learning, New Edition: Cambridge. Cambridge University Press. 